\title{
Integrating Sustainability into Management of Project
}

\author{
Hosein Daneshpour
}

\begin{abstract}
Sustainability is one of the most significant challenges that societies face today. Over recent years environmental considerations have become an important part of all projects and companies are integrating sustainability in their strategy. The need for sustainability is the crucial factor for projects success and project management as a key skill need to develop to execute and guide the project in a sustainable way. The purpose of this work is to discuss the concept of sustainability, highlighting it application in project management and introducing the potential area of integration of sustainability idea in project management. Consequently aiming at providing the insight and increasing the awareness of project oriented organizations concerning sustainability issue.
\end{abstract}

Index Terms-Sustainable business and technology, sustainable project management, environmental engineering, education in sustainable development.

\section{INTRODUCTION}

Sustainable development has been incorporated into different levels of society in the recent years and Projects as instruments for change affect the sustainable development greatly. Sustainability is one the most important issues that need to be taken into account in decision making process in different levels of project oriented organizations; hence it is important to know how to move from theory into practice. Dramatically the current ways of exploitation of the natural resources are not sustainable, we need to change them and it is inevitably related to projects and therefore to the strategies of organizations. Thus the demand to move from the current and traditional approach of project management toward a sustainable management is a necessity; in order to change the profession of project management into a true profession [1].

The idea of integration of sustainably into project management highlights the complex aspect of professional project management, not only from technical point of view but also because the project manager should deal with organization factors that are beyond its control. Initially the idea was introduced At IPMA World Congress 2008 where the importance of sustainable project management was emphasized and this notion was proposed that "the further development of the project management profession requires project manager that take the responsibility of sustainability". Then at IPMA expert seminar on 2010 several discussions on the integration of sustainability in projects and project management were raised and although until now some researches has been done in this area, but it is still an emerging field of study [2].

The following study explains the concept of sustainability and it application in project management and express that the

Manuscript received May 25, 2014; revised July 16, 2014.

Hosein Daneshpour is with the Lappeenranta University of Technology, Finland (e-mail: hos_da@yahoo.com). role of project management should be by far higher than the delivery of project and it has the responsibility of correct incorporating of sustainability in Project management.

\section{SUSTAINABILITY AND BACKGROUND CONCEPT}

How and when sustainable development idea started? Garrett Hardin in 1968 discussed the term "tragedy of the Commons"; it highlight that the solutions to over use of the natural resources on earth will not happen only by science, but will need moral and economic decisions [3]. Then in 1972 the club Roma explored the idea further by introducing the book of "the limits to the growth" that aimed at challenging the idea of progress or growth [4]. these dabates led to the world Commission on Environment and Development in 1987 (Bruntland Commission). Bruntland Commission defeins sustaniable development as "Ensuring that development meets the needs of the present, without compromising the ability of the future generations to meet their own needs" [5].

The term sustainability integrates social, environmental and economic responsibilities. Elkington, co-founder of sustainabailty, explains it in the form of triple bottom line or people, planet and profit (PPP) (Fig. 1); sutainabilty is about balancing between economic, socail and environemnt [6], [7].

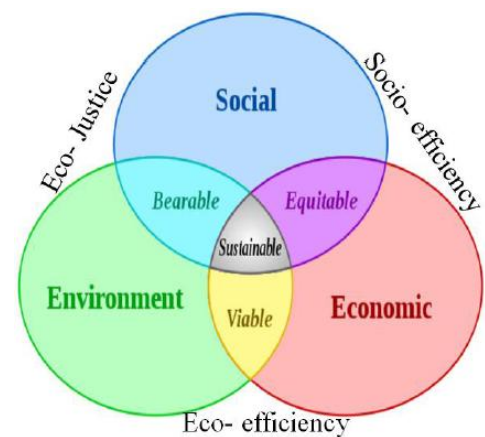

Fig. 1. The triple bottom line concept of sustainability [1]

There are some tools and techniques that can be utilized for assessment of sustainability; they can be divided into three main categories. The First one is indices: These are indicators and indices that can help to assess the sustainability. These indicators are quantitative measures that have the following main characteristics: they are simple, have a wide scope and allow evaluation of trends such as ecological footprint [8].

The second category in sustainability measuring is Product related assessment tools that assess flows related to the production and consumption of goods and services. Life cycle assessment is one the most important tools in this group that evaluate the environmental impacts of a product or a service throughout its life cycle. Also Ecological rucksack is another well-known index; the ecological rucksack defines 
the actual material intensity of a product and can identify all the materials required for the complete production process minuses the actual weight of the product. The rucksack factor is the quantity (in $\mathrm{kg}$ ) of materials extracted from nature to deliver $1 \mathrm{~kg}$ of the resource. For example the rucksack factor for aluminium is 85 (so $85 \mathrm{~kg}$ of materials moved for production of every $1 \mathrm{~kg}$ of aluminium), this value for an aluminium drink can is $1.2 \mathrm{~kg}$ or for a 5 gram gold ring is $2000 \mathrm{~kg}$ ! [9].

The third umbrella is integrated assessment tools that are utilized in policy or project evaluation to achieve a more comprehensive approach. For instance System dynamic models which rely on computer modelling is one the useful tools in developing a sustainable model. Fig. 2 illustrates a diagram of sustainability categories that has been mentioned [8].

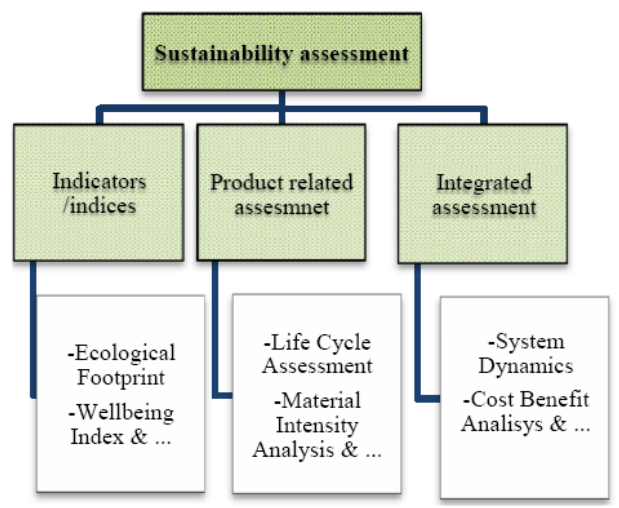

Fig. 2. Framework for sustainability assessment tools and examples.

In another perspective, these analytical tools for environmental management are meant to facilitate the environmental strategies behind sustainability and reaching the aim of "eco-efficiency". Fig. 3 presents the basic the Basic environmental strategies of sustainability [10].

Eco-efficiency is action that its goals are to produce more products, services and welfare with minimum use of natural resources. Eco-efficiency simply seeks the goal at which increase the profits while simultaneously environmental damage per unit of output will decreases, which can be formulated as:

$$
\text { Eco }- \text { efficiency }=\frac{\text { outputs }(\text { Product or Service provided })}{\text { inputs }(\text { Energy and materials used })}
$$

But an important challenge that should be taken into account carefully is the efficiency "trap" that environmental managers might catch in if they try to reach the aim just by pursuing the eco-efficiency, solely. So the problem rises from a misleading assumption that the side effects of increasing efficiency can be compensated by being more efficient, while there is a clear distinction between the reduction of side effect and fulfillment of purpose that should always be taken into consideration. However, the solution to efficiency trap is protective measures that need to be implemented even though they do not help the business in its main purpose [11].

When it comes to sustainability concept in business, corporate social responsibility (CSR) is an undeniable factor that cannot be neglected. CSR can be simply explained as "doing well by doing good". The modern conception of Business in society do not focus on maximizing profit or money and instead highlights that businesses has corporate responsibility not only to its shareholders to share profit but also to the public and the society it trades in; corporate responsibility can come down to the ethics of a business [10], [12]. CSR is not just about "doing good" but "avoiding bad" is also a necessary part of CSR to prevent corporate social irresponsibility (CSI) [13].

There are several definitions for corporate responsibility; Blowfield and Frynas, concerning corporate social responsibility states that companies have responsibilities that sometimes go beyond legal compliance and that they have responsibility for others with whom they do business. In another vision CSR can be categorized into three types: Philanthropy, integrated and innovative [14], [15].

From business prospective there are different levels of corporate social responsibility that start with compliance with legislation and good practices which is at the bottom by assuming a pyramid shape, then goes up to meet the expectations of stakeholders and proactive responsibility (rather than being reactive) and finally at the top of the pyramid is building a competitive advantage [16].

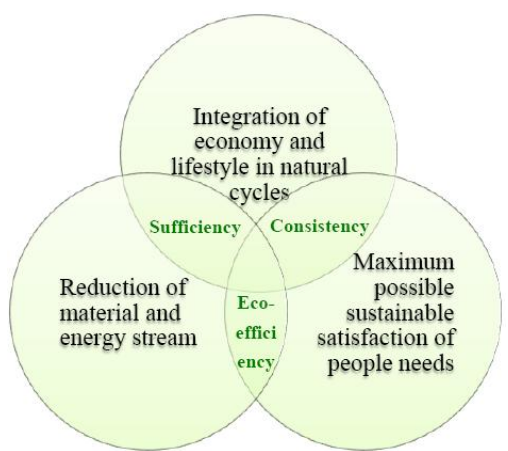

Fig. 3. Environmental strategies behind sustainability [10]

\section{Sustainable Magamnet of Resource}

The term resource (human, natural and social resources) can be regarded as the corresponding term of capital as production factor, in the notion of integration of the principle of sustainability into management and can be illustrated with the following formula [11]:

$$
\text { Sustainability }=\frac{\text { Resource supply }}{\text { Resource consumption }}=1
$$

The term resource is rooted in management studies and therefore in sustainable management and treatment of resource. In a holistic approach; sustainable management of resource can be carried out by tools that have the ability to control the flow of business's resource clearly (both material and immaterial resources). The SWOT analysis, strategic sustainability vector, resource oriented sustainability monitoring and control of resource regimes are some of the innovative measures. Some of these tools such as strategic sustainability vector are rather didactic instruments while the resource oriented sustainability monitoring is developing more practical frameworks and basically its aim is to include all activities leading to a reduction of side effects caused by economic activity. It emphasizes that the sustainable operation cannot be achieved only through efficient application of resources but business should also focus on 
resource supply and this approach place the firm as a resource dependent system with purpose of production of resources for the environment sustainability against the old concept that considers the firm as a value creating system purposed to make profit by producing goods and services [1], [11]
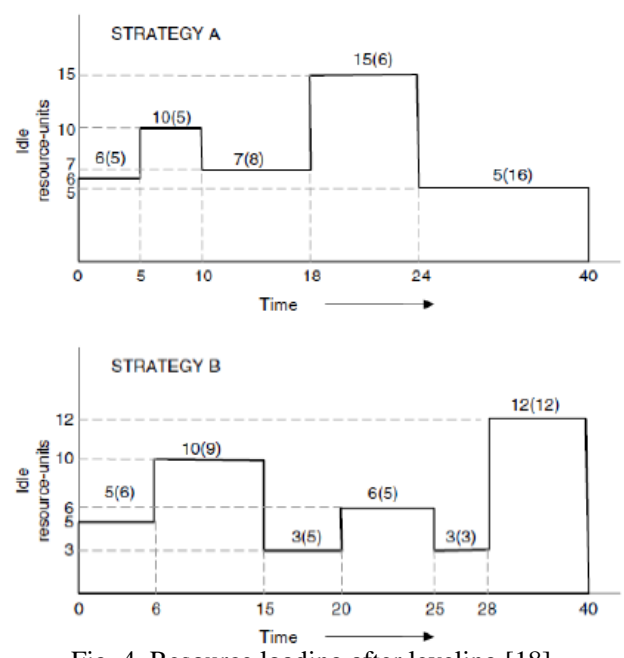

Fig. 4. Resource loading after leveling [18].

In addition, in a more detailed scale and considering the idea in Fig. 3, can better exhibit the relationship of project planning and the sustainability concept; an example in this case can be the resource allocation and "levelling" in projects management and planning. PMBOK explains resource levelling as process of development of fluctuation in resource load to facilitate stable level of the work force or form sustainable prospective it means to do the same job with less resource. Resource levelling techniques can help to decrease the excess resources and facilitate resource usage that lead to reduction in demand and costs [17]. Fig. 4 shows a hypothetical resource graphs for the two alternate strategies for 6 resources [18]:

$$
\begin{aligned}
& \text { Area } A=6(5)+10(5)+7(8)+15(6)+5(16)=306 \text { resource } \\
& \text { Area } B=5(6)+10(9)+3(5)+6(5)+3(3)+12(12)=318 \\
& \text { resource }
\end{aligned}
$$

As the area in A is less than B then strategy A is more efficient and provides us a more sustainable approach.

Today in case of management of mega projects there is possibility to take the advantages of software that can do such calculations quickly and accurately and the most well-known among them are Microsoft and Primavera. For instance Primavera software has predicted the option of resource leaving in its menu that facilitates to reach this aim. But the main critique still remain intact: there is a close relationship between software and standards of project management (such as PMBOK) while these standards, themselves, have failed to respond the need of sustainability and environmental management suitably. Despite the promising improvements in project planning software in the current decade, it can clearly be observed that still this software are focusing to meet the need of project management according to iron triangle and regardless of pillars of sustainability; People, plant and environment [19].

The next section describes the potential and the possibility of integration of Sustainable Development and the project management.

\section{InCORPorating Sustainability In PROJECT MANAGEMENT}

The concept of sustainability has been recently been implemented in the project management knowledge area while sustainability and project management are in contrast to some extent. Table I describes the main area of contrasts [20].

TABLE I: The CONTRAST BETWEen THE CONCEPTS OF SuSTAINABLE DEVELOPMENT AND PROJECT [1]

\begin{tabular}{|c|l|}
\hline Sustainable project management & Traditional project management \\
\hline Long term and short term oriented & $\longrightarrow$ Short term oriented \\
\hline In interest of both current and future generation & $\longrightarrow$ In the interest of stakeholders \\
\hline Life cycle oriented & $\longrightarrow$ Deliverable oriented \\
\hline People, Planet, Profit & $\longrightarrow$ Scope, Time, Budget \\
\hline Increasing complexity & $\longrightarrow$ Reduced complexity \\
\hline
\end{tabular}

In order to translate the main criteria of sustainably concept into capability of companies there are some indicators that can be utilized by companies to assess their current levels in different perspective and also facilitate to bridge the gap between actual and desired levels. The Global Reporting Initiative (GRI) that is an organization pioneer in sustainability reporting has developed a checklist for considering sustainability in projects and project management. A developed form of checklist is presented in Table II, basically it has the potential to be broken down to more details and be used by project manager to assess the project in different levels of consideration such as project resources, business process, business model and deliverables [1].
In this study the project is considered as temporary organizations that are in connection with the non-temporary or permanent organization. The main principles of sustainably that can be a guideline in the implementation of sustainability concept in project management are the followings:

1) As mentioned in chapter two; Sustainability is about harmonizing social, environmental and economic pillars and companies should try to satisfy all of them. The current projects management method focuses on the triple constraints (time, cost and scope) or in other words just profit (P).

2) Sustainability focuses on the long term as well as short term goals, while long term vision is out of the boundary 
in the current definition of project management.

3) Companies are under influence of international stakeholders so sustainability is related to both local and international orientations. If the businesses are globalized then consequently project management should be globalized too.

4) Sustainability is about consuming incomes and natural capitals remains intact. Moreover company should manage their social and environmental capitals as well.

5) Transparency and accountability are important component of sustainability. Companies need to prove clear and regular report concerning their decision and social and environmental effect of their actions to all potential stakeholders also the company accepts responsibility of its actions and polices.

6) Sustainability is not a fixed goal is direction of movement and a key element of sustainability is "change" towards a more sustainable business, therefore personal value and ethics are critical elements.

Although it is necessary to be aware of the sustainably integration concept it is also important to move from theory into practice. To put sustainability concept in to practice basically three levels for integration can be considered: Personal (project manager), project and organization level. These sections focus on the case of project level: to answer how will it affect the project management processes [1]?

TABLE II: CHECKLIST FOR INTEGRATING SUSTAINABILITY IN PROJECTS AND PROJECT MANAGEMENT

\begin{tabular}{|c|c|}
\hline \multirow[t]{2}{*}{ Economic Sustainability } & $\begin{array}{c}\text { Return on Investment and Economic } \\
\text { Performance }\end{array}$ \\
\hline & Business Agility and Flexibility \\
\hline \multirow{5}{*}{$\begin{array}{l}\text { Environmental } \\
\text { Sustainability }\end{array}$} & Transport \\
\hline & Energy usage and Emissions \\
\hline & Waste recycle and disposal \\
\hline & Water usage and recycling \\
\hline & $\begin{array}{l}\text { Materials and resources Reusability } \\
\text { and Supplier selection }\end{array}$ \\
\hline \multirow{4}{*}{ Social Sustainability } & Human Rights \\
\hline & Labour Practices and Decent Work \\
\hline & $\begin{array}{l}\text { Society, Customers and Product } \\
\text { Responsibility }\end{array}$ \\
\hline & $\begin{array}{c}\text { Return on Investment and Economic } \\
\text { Performance }\end{array}$ \\
\hline
\end{tabular}

Based on the methodology of PMBOK standard, project management processes can be defined in five process groups: initiating, planning, executing, controlling and closing. According to a research done on a group of projects; for each process group the extent that scope and objectives of the project provide opportunities for integrating sustainability and also the opportunities that project provides for integration has been evaluated. Therefore it revealed that although the potential of integration of sustainable development and project management exist in all process groups but the area and the level of integrations varies. For instance the initiating process has high potential to integrate the concepts of sustainability into the content (objective, intended result, deliverable) of the project, while the controlling process provide more opportunity for Integrating the concepts of sustainability in the process of the project. Fig. 5 illustrates the best areas to integrate sustainable development into project management [1], [21].

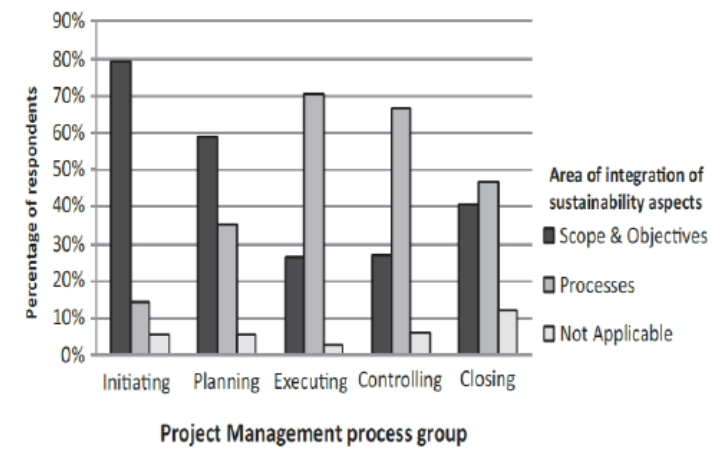

Fig. 5. Areas to integrate sustainable development into project management.

In the same approach, the impact of the main sustainability principles on project management processes has been recognized. As it is expected both transparency and accountability and Personal values and ethics have the most impact on project management process [1].

In this pathway Project managers are in the frontline of organizations to achieve sustainability. EU conference of PMI explained the importance of issue that: 'Corporate social responsibility is too big an issue to leave to someone else to address' and Project management will change from 'doing things right' to 'doing the right things right [22].

For this reason, Integration of sustainability extend the system boundary of project management, in other words it emphasis the idea of corporate social responsibility that full life cycle of project should be included and full life cycle of project basically include: project life cycle, asset life cycle and product life [1], [17].

One the most significant hindering forces in the integrating of sustainably is the difficulty of incorporation of social and environmental dimensions of sustainability in programs and projects. There have been some researches to develop a structure to fulfill this integration in the operational term although some are still conceptual framework but among this method Integration of environmental issue and performance measurement systems (PMS) present a good potential. The Balanced Score card (BSC) that is one the most popular performance measurement systems has been the most widely utilized and recommended tools between companies in order to translate the nonfinancial issues of sustainability into their objective. BSC define the goals that organization is going to monitor in four perspectives: financial, customer, internal and Learning \& growth through defining performance indicators and proper targets. The main barriers of BSC are ranging from the willingness of CEO, through uncertainty about future role of BSC to function of the current reporting system [23]-[25].

In addition a main challenge is also that project management standards could not meet the sustainability needs. The most Well-known standards neither discussed the important of sustainably nor the methods to impalement or integrate. For instance the construction (extension) guide to the PMBOK has reviewed the important of environmental management briefly and mentioned three processes for environmental management superficially (environmental planning, environmental assurance and environmental 
control). The standards also sometimes try to take advantages of ISO 14000 standards while these series of ISO standards has faced with some weakness and failed to adequacy response to the needs Environmental management [26], [27].

It is expected that this integration change the Project management profession. The main challenging areas are:

- System boundaries?

- How to apply in practice the sustainability concept in project management?

- What are the implications of the integration for managers and organizations?

- And also how to measure and monitor it further?

Raising organization awareness of environmental issues is an important step toward increasing sustainability measures in any company. Basically Environmental learning process in an organization comprises of two main components: individual and social, Nevis explains that this learning process can occur in three phases: Acquisition, Distribution and Utilisation of the knowledge [28].

\section{CONCLUSION}

Organizations are seeking more sustainable and environmental friendly approach in their projects and it is basically expected that the concept of sustainability be reflected in project management.

The traditional projects management and sustainable project management are in contrast to some extent. In tradition project management iron triangle is based on Time, Budget and scopes (regarding Quality), while now it is perceived that the condition is more complicated and three important elements of Social, Environmental and Economic should be considered reasonably. The impact of the principles of sustainability on projects and project management showed that these principles shift the scope of management the project. It is essential that organizations and project managers take the responsibility of the results of their project in a full life cycle.

Societal request for sustainable development is increasing and make the project management a challenging issue in future. Some standards of project management have mentioned about the environmental awareness and management but it has not adequately recognized or explained a method, consequently stakeholder management that is a significant item in sustainability management is not treated thoroughly in the project management standards. The main challenges in this integration are the system boundaries and also despite all attempts done up to now such as application of performance measurement tools, still the need of a method for practical implementation is required. There is a growing need of knowledge and concepts to practically implement the sustainability in project management.

\section{REFERENCES}

[1] G. Silvius, R. Schipper, J. Planko, J. van den Brink, and A. Köhler, Sustainability in Project Management, Gower, 2012.

[2] J. vom Brocke, S. Seidel, and J. Recker, Green Business Process Management, Springer, 2012

[3] C. Wilkinson and B. Salva, "Coastal resource degradation in the tropics," Marine Pollution Bulletin, vol. 64, pp. 1096-1105, 2012.
[4] G. M. Turner, "Comparison of the limits to growth with 30 years of reality," Global Environmental Change, vol. 18, pp. 397-411, 2008.

[5] U. Nations. Report of the world commission on environment and development: Our common future. [Online]. Available: http://www.un-documents.net/our-common-future.pdf

[6] S. Lee, Y. J. Geum, H. Lee, and Y. Park, "Dynamic and multidimensional measurement of product-service system sustainability," Journal of Cleaner Production, vol. 32, pp. 173-182, 2012.

[7] J. Elkington, Cannibals with Forks, Oxford, 1997.

[8] B. Nessa, U.-P. Evelin, S. Anderbergd, and L. Olssona, "Categorising tools for sustainability assessment," Ecological Economics, vol. 60, no. 3, pp. 498-508, 2006.

[9] C. H. Eccleston, Frederic March and Timothy Cohen, Inside Energy: CRC Press, 2001.

[10] S. Schaltegger, R. Burritt, and H. Petersen, An Introduction to Corporate Environmental Management. Striving for Sustainability, UK: Greenleaf, 2003.

[11] G. Muller-Christ, Sustainable Management Coping with the Dilemmas of Resource-Oriented Management, Springer, 2011.

[12] S. O. Idowu, N. Capaldi, L. R. Zu, and A. D. Gupta, Encyclopedia of Corporate Social Responsibility, Springer, 2013.

[13] L.-H. Nick and K. Müller, "The CSR bottom line: Preventing corporate social irresponsibility," Journal of Business Research, pp. 1928-1936, 2013.

[14] M. Blowfield and E. George, "Critical perspectives on Corporate Social Responsibility in the developing world," International Affairs, vol. 81 , no. 3, pp. 499-513, 2005.

[15] M. Halme and J. Laurila, "Philanthropy, integration or innovation?" Journal of Business Ethics, vol. 84, pp. 325-339, 2009.

[16] J. O. Okpara and S. O. Idowu, Corporate Social Responsibility: A Review of the Concept and Analysis of the Business Case for Corporate Social Responsibility in the Twenty-First Century, Springer, 2013.

[17] PMI, A Guide to the Project Management Body of Knowledge Pmbok, Project Management Institute, 2008.

[18] A. Badiru, "Resource analysis and management," Industrial Project Management, CRC Press, 2007.

[19] Primavera, Primavera Training Manual - Course 106, Primavera, 2006, p. 329.

[20] M. Eid, Sustainable Development: Rethinking Relationships in the Construction Industry; Integrating Sustainable Development (SD) into Project Management (PM) Processes, LAP Lambert Academic Publishing, 2009.

[21] M. Eid, Integrating Sustainable Development into Project Management Processes, The University of Edinburgh, 2004.

[22] J. Russell. (2008). Corporate Social Responsibility: What it Means for the Project Manager. [Online]. Available: http://congresses.pmi.org/NorthAmerica2008/documents/GBS04.pdf

[23] M. A. Sánchez, "Integrating sustainability issues into project management," Journal of Cleaner Production, pp. 1-12, 2014.

[24] A. Lansiluoto and M. Jarvenpa, "Greening the balanced scorecard," Business Horizons, vol. 53, pp. 385-395, 2010.

[25] S. Tonchia and L. Quagini, Performance Measurement Linking Balanced Scorecard to Business Intelligence, Springer, 2010.

[26] P. Eskerod and M. Huemann, "Sustainable development and project stakeholder management:what standards say," International Journal of Managing Projects in Business, vol. 6, no. 1, pp. 36-50, 2013.

[27] S. Curkovic, R. Sroufe, and S. Melnyk, "Identifying the factors which affect the decision to attain ISO 14000," Energy, vol. 30, no. 8, pp. 1387-1407, 2005.

[28] Nevis, "Understanding organizations as learning systems," Sloan Management Review, vol. 36, 1995.

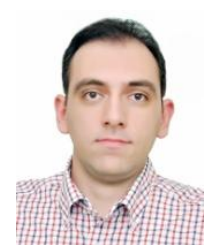

H. Daneshpour was born in Tehran in 1983. He has done his bachelor study in industrial engineering in industrial production at Azad University of Tehran from 2001 to 2006, then he subsequently fulfilled master program in the field of environmental energy technology at Lappeenranta University of Technology in Finland in 2014

He has several years of working experience as a project lead planner in the field of EPC project managements of combined cycle power plant, he is a competent user of project management software such as Primavera and is skillful in implementation of well-known project management standards such as PMBOK. 